\title{
Education Towards Jewish Values in the Israeli State Preschool: Its Character, Essence, and Scope
}

\author{
Nitsa Dori \\ Correspondence: Nitsa Dori, Director of Early Childhood Department at the Shaanan Teachers' College, Haifa, Israel.
}

Received: March 11, 2019

doi:10.11114/jets.v7i8.4317
Accepted: June 5, 2019 Online Published: June 6, 2019

URL: https://doi.org/10.11114/jets.v7i8.4317

\begin{abstract}
A Jewish-Israeli identity incorporates two identities—Jewish and Israeli, and various philosophers suggest different ways to view the combination or separation of these identities. Agasi and Samucha come from different approaches to suggest ways of integrating both identities. They speak about the existing division between the two identities, in light of the unique characteristics of the State of Israel. The ever-increasing essential need for providing a significant and systematic solution to the issue of value-based education and nurturing the Jewish-Israeli identity of the students of the State education system must be seen in light of the collapse of values in many postmodern Western societies. The existing education system perpetuates the division into sectors that divides Israeli society from within. At the same time, the emphasis in State preschools examined in this article, is on culture and nationalism, as connected to values of good behavior towards others. The findings show that Jewish education at an early age is influenced by the personality and inner world of the preschool teacher and her own connection to Jewish content, irrespective of the educational stream to which the preschool belongs.
\end{abstract}

Keywords: Jewish identity, Israeli education system, State preschools, religious preschools, educating to acquire cultural values

\section{Introduction}

The origins of this article lie in the World Bible Quiz held on Israel Independence Day, 5777 (2017). The winner was Sagiv Lugasi, a student at the Ort Maalot School, the first winner for thirty years who studies at a State school (Note 1). The occasion was widely discussed throughout the media and awakened the wish to further research the topic of Jewish studies in State education at the beginning of a child's education, in the State preschools. The study examined a small sample in different areas of Israel regarding the approach of State education preschool teachers to this issue, using three parameters: Welcoming the Sabbath ceremony, Jewish festivals, and Torah stories (Note 2). Since the publication of the Shenhar report (1994), the Ministry of Education has called for the issue of shaping Jewish-Israeli identity for students in the Jewish-State system to be addressed comprehensively through a broad prism of a pedagogic continuum from preschool to 12 th grade. The program for Jewish-Israeli renewal that the Ministry is currently building suggests rationale and modes of action in both the formal and informal areas of school communities and the public setting. All this emerges from a desire to return the responsibility for pluralistic, democratically-committed Jewish-Israeli identity to the society and community of origin of the State education system students, in line with this community's worldview and values: "The curriculum of Jewish-Israeli culture is intended to strengthen it and deepen the students of the State education system's Jewish-Zionist-Israeli identity, and sense of belonging, responsibility and commitment to their nation, heritage, and culture" (Israeli Ministry of Education, 2017). The program seeks to expose the students to significant, multi-faceted, and contemporarily relevant Judaism within a broader Israeli context, and provide them with wide and in-depth knowledge, rich experiences, and a variety of innovative tools to develop the students' characters and identities as Jews, Israelis, and human beings.

The curriculum includes a central place for in-depth study of a range of sources from the Jewish library as an essential component and resource that is life-changing and arouses thought and inspiration during the students' character and identity development. This is hoped to deepen their ability to maintain attentive and respectful dialogue between different identities in Israeli society. The point of departure of having values enables emphasis to be placed on what is shared and unifying among the various population segments through the important common values on which the program is based. In addition, the intention is to encourage the students to actively participate in developing a Jewish-Israeli culture in public space, in the school climate, and within the community later in life too, as graduates of the education system. All of this is due to a wish to 
impart Jewish studies with positive significance rather than cause alienation, contributing to the building of the identity and world of values of the graduate of State education in Israel.

The purpose of this article is to examine - using a small, random, and unrepresentative sample, of course - the attitude of secular parents from State preschools to this policy. What is the attitude of the State preschool teachers to education toward Jewish values and study of Jewish cultural heritage in State preschools? What do they choose to emphasize? Do they feel coercion regarding this issue, or do they teach it willingly being personally familiar with its importance? Do they have conflicts with parents when teaching clusters of Jewish knowledge units?

\section{Literary Review}

\subsection{The Development of Jewish-Israeli Identity in Israel}

In a study by Michael Zelba (2017), in which he examined surveys conducted by the Central Bureau of Statistics (CBS) during 2002-2012, he discovered that although secular Jews have a lower birthrate, higher emigration rates from Israel, and even not infrequently become religious, they have maintained their percentage within the population and constitute $43 \%$ of the population (Lax, 2017). This situation is not something fleeting, but rather has already existed for twenty years. Zelba based himself on the CBS Social Survey which divides the adult Jewish population into five categories: ultra-Orthodox, religious, traditional-religious, traditional-not so religious, and secular. He saw that only $50 \%$ of those who had grown up in a religious household define themselves as religious in adulthood. A small number, 5.5\%, had become ultra-Orthodox, and the rest were distributed among lesser levels of religiosity, with many having become "traditional-not so religious". At the same time, not only religious, but also traditional Jews, had joined the secular community. Thus the rate of secular Jews within the population had remained constant. Zelba also revealed that $16 \%$ of the secular Jews had become stronger believers.

Jewish-Israeli identity incorporates two identities-Jewish and Israeli, and many philosophers suggest different ways to view the combination or separation of these identities (Hartaf, 2007). Agasi (1993) and Samucha (2000) speak about the division that exists between the two identities, in light of the unique characteristics of the State of Israel. Schweid and Porat (1991) explain this according to the original Zionist philosophy that views Judaism as a culture and/or a cultural tradition. The Zionist outlook led to a lack of clarity regarding the religious dimension in Israel's collective identity, and thus reinforced the combination of both identities, even unconsciously (Fischer, 2003). Other approaches suggest ways of combining the two identities. Ahad Ha'am (1954) saw the State of Israel as combining the material (a state framework) with the spiritual (the Jewish spirit), so as to be able to provide a future center of identity and strength for all the Jews of the world. He emphasized that "there is no Judaism without Jews, and no Jews without Judaism... both are intertwined as a body and soul". Kaplan (2004) proposed viewing Judaism as a civilization, as more inclusive than the Jewish religion, and including its history, literature, language, customs, tradition, art, modes of behavior, values, etc. Schweid and Porat called for a combination of Jewish and Israeli identities, arguing that Israeli identity in of itself is not rich or "full" enough to be a basis for life values. Schweid (2000, pp. 75-77) writes that Israeli secular society is undergoing a great crisis, and can only be saved by imposing a real change on its attitude toward Jewish religion and tradition, based on a positive, authentic outlook toward religious values, empathetic study, and a cultural experience within the individual, familial, and communal lifestyle. The ever-increasing essential need to provide a significant and systematic solution to the issue of value-based education and nurturing the Jewish-Israeli identity of the students of the State education system must be seen in light of the collapse of values in many postmodern Western societies (Sarid, 2012).

The collective identity of the "traditional Jew" was the embodiment of the Diaspora Jew; the collective identity of the "new Jew" was the embodiment of the Jew in Eretz-Israel during the early twentieth century. The "new Jew" eventually evolved into the "sabra" who became the Israeli collective identity and also influenced and determined the ideal character of the Jew in Israel (Almog 1997, p. 14; Shapira 1997, p. 15). The aspiration to create a singular Israeli identity, compatible with the "melting pot" attitude, can also be seen in school literature readers during the 1950s and 1960s-the same readers that served as "agents for collective memory, that was a major component in the forming of Israeli identity" (Davidson, 2000, p. 32).

\subsection{Contemporary Jewish-Israeli Identity}

Various researchers note that we cannot speak of one Jewish-Israeli identity in early twenty-first century Israel (Ben-Rafael 2001; Kimmerling 1998; Oron 1993; Shapira 1997). Ben-Rafael (2001) argues that economic, social, and cultural processes have led to a shattering of the Zionist pioneering myths, and to viewing Jewish-Israeli identity as an "objective" social fact that is the inevitable outcome of the existence of a sovereign Jewish society. Questions such as "how Jewish is it", "how is it Jewish" and "what makes it Jewish" have become part of the public agenda rather than just being of interest to the individual. Hartaf (2007) notes in her study that Ben-Rafael is speaking about three different paths which stemmed from this situation regarding collective identity: 
- The place of religion in the collective led to ultra-Orthodox, national religious, and non-religious identities.

- Defining the commitment to the collective rather than other, smaller communities, led to the formation of ethnic identities-a Mizrahi-Sephardic identity, the identity of immigrants from the FSU, and an Arab-Israeli identity.

- The attitude towards the place-status of the collective in relation to others expresses the dilemma between the two affinities. One-the affinity with the Jewish world from which the Zionist philosophy had emerged, and two-the affinity with the location, the Middle East, where the territorial entity exists. The second affinity led to the formation of the Israeli-territorial identity, differentiating between the "Israeli nation" and the "Jewish world" (pp. 65-79).

\subsection{Separation of Jewish and Israeli Identities}

Hartaf (2007) also emphasizes in her study that a 1989 study conducted among teaching students revealed that the connections between Jewish and Israeli identities had become more tenuous and that each identity tended to remain within its own area (Prego 1989, p. 270). In contrast, four years later, Oron (1993) also researched the Jewish-Israeli identity question among a national sample of Israeli teaching students in teaching colleges and seminaries in three educational sectors: State, State Religious, and independent (ultra-Orthodox). The research findings show that, "it is very difficult to speak of a Jewish-Israeli identity as one thing... the identity of the Israeli is not solely Israeli or solely Jewish" (p. 160), but rather a combination of Jewish and Israeli components in differing amounts. He concludes that the education system must aspire to recognize the plurality and reach an "educational process that will lead to true identification with positive, relevant, living, and creative Judaism that is connected to, and draws from, generations of Jewish culture, so that the young Jew will choose it” (p. 169). Shapira (1997, p. 15) and Kimmerling (1998, pp. 264, 306) also speak of the multiple identities in Israeli society and the need to emphasize more what unites people than what separates them, since there is no one Israeli identity. However, there are researchers (Agasi, 1993; Samucha, 2000) who suggest separating the identities and changing from a religious to a nation state: that the State of Israel will be a secular state, retaining its religious-Jewish character but separating religious institutions from the government. Fischer (2003) argues that Zionism has brought about a situation in which the collective Israeli identity lacks clarity regarding the religious dimension. The majority of the public dissents and does not observe the traditional religious laws, but continues to view part of its collective identity in the religious dimension (p. 63).

Eliezer Schweid, one of the most prominent thinkers calling for Judaism's inclusion in Israeli life, emphasizes that Israeli identity is "an identity that integrates cultural and historical baggage that is too poor to support creative life rich in content and expression, from the viewpoints of both individuals and the group who identify" (Schweid and Porat, 1991, p. 4) and proposes how to integrate Jewish heritage into the lives of non-religious Jews. He believes Jewish identity possesses several comprehensive and rich facets:

- It reflects identification with the Jewish nation.

- Religion is the central focus of values, norms, and symbols.

- Someone cannot create significant self-identification with Judaism without a positive attitude towards what makes up tradition and the Jewish religion, and a secular Jew can also create a positive cultural attitude toward religious content. If so, there is no reason for a secular Jew to relinquish the rich content, "the experiences of the Sabbaths, festivals and special days, the Jewish Bible, the religious literature including Jewish legal and exegetical texts, religious poetry, the prayers and Jewish religious philosophy" (p. 5).

- The development of Jewish cultural pluralism, based on mutual tolerance and respect between the different Jewish movements and communities. Therefore, a rich Jewish-Israeli identity or Jewish-Zionist identity demands adoption of "the content of the cultural and historical memory of the Jewish nation, meaning about Judaism as the heritage of an independent culture" (Schweid, 1996).

Shachar (2017) notes that Israeli identity is not one particular path. Also, the feeling of national identity of the Jewish Zionist majority in the State of Israel is not static and homogenous. Over the decades of the existence of a Jewish and democratic state in the Land of Israel, its residents' identity has constantly changed. Shachar quotes Shapira (2007) who states that two general stages can be identified: the first was during the State's early decades, and was characterized by a collective-propagandist identity, based on the ethos of sacrifice for a common goal-the State. The second stage, that is still in effect, is characterized by an individualist-utilitarian identity that rejects any ideology or collective goal. Israeli identity is still being reformulated. Several social and political factors hastened the demise of the old narrative and led Israeli society, consciously or otherwise, to a process of rethinking its values (pp. 274-275). 


\subsection{The Secular Population's Attitude to Religion}

In 1994, the Guttman Center of the Israel Democracy Institute conducted a survey regarding faith and affinity to tradition. Of the respondents, 56\% answered that they believed unreservedly that the Torah was given on Mount Sinai and only 15\% said that they do not believe in it at all. Almost $80 \%$ fast on Yom Kippur (the Day of Atonement) (Levi, Levinhson, and Katz, 2002).

According to Mimron (2009), the traditional population who are divided between State and State Religious education are hurt by the place Jewish education occupies in the education system and from this State/ State Religious divide in education. In State education, not only are there too few educational expressions of their traditional world within school life, but traditional practices such as kissing the mezuzah, keeping kosher, and going to the synagogue, are not accepted as natural. Moreover, the curriculum and teaching methods are shaped with the population of secular students in mind. The limited occupation with Jewish education as part of the school activity also contradicts the traditional identity of many of the students in State education. This creates a situation in which, while the traditional students' Jewish identity is important to them and they are interested in learning and doing more, the school does not view Jewish education as being of great importance. There is a gap, sometimes sharp, between the Jewish world of the home and school. In State Religious education the traditional students are not considered religious or serious enough regarding Judaism.

Being a secular, Zionist, Israeli can often mean being torn between Universalist humanist values and the desire to preserve the unique ethno-nationalist character of the Jewish state (Tsabar Ben Yehoshua \& Stein, 2007). The increasing trend of pluralistic Jewish studies among secular Jews, can be viewed as an attempt to cope with this tension.

\subsection{The Development of State Education in Israel-A Historical Review}

\subsubsection{Israeli Identity in the Nascent State of Israel}

Inbari (2016) argues that the term Ivriyut has three different meanings. Ben-Gurion sought, as already noted, to wipe out the Diaspora Jewish identity, so as to resurrect biblical Ivriyut (being of the Hebrew race) (Don-Yihye, 1989; Shapira, 1997, 217-247; Tzivyon, 1988). Ben-Gurion failed vis-a-vis building the nation. He failed, not because he tried to build a nation, but because he tried to build an artificial nation. There is no "Israeli" nation. There is a Jewish nation. It was the Jewish nation that needed a melting pot, but Ben-Gurion made believe he could create a substitute. Overenthusiastic regarding the negation of Diaspora Judaism, he did not understand the difference between a non-Diaspora melting pot and a non-Jewish one. He should have grasped that the purpose of Zionism, beyond the basic Herzlian purpose, was to create a non-Diaspora Jewish identity in the Land of Israel.

The question of the State of Israel's character as a "secular" or "Jewish religious" state remained unsolved at its establishment. At that time, secularism did not see religious Jews as a threat to its status. The transformation began in recent decades, with the rise in the proportion of the population who are national religious and ultra-Orthodox. Therefore, the secular establishment is afraid of a religious-ultra-Orthodox majority by the year 2030 (Bystrov \& Soffer, 2010).

\subsubsection{Jewish and Democratic Values in the Modern State Education}

According to Professor Ruth Gavison, a senior official at the Israel Association for Civil Rights (ACRI) and one of those responsible for formulating the Nation-State Bill, "Israel will not be able to be a Jewish and democratic state in the long-term, if it does not accept responsibility for developing the Jewish identity of secular Jews who do not observe Jewish law, and strengthening the democratic and humanist component in the identity of religious Jews. If we succeed in this, Judaism will once again become something common to the members of the Jewish nation whatever their approach to observing Jewish law, and not remain the monopoly of the Jewish Orthodox establishment" (Note 3).

A document prepared for the Israeli government by the Jewish People Policy Institute, founded by the Jewish Agency for Israel, states, "We recommend that the State of Israel strengthen the status, role, and level of official participation of the non-Orthodox Jewish streams (including those of secular Jews) in the religious life of the state, so as to increase and emphasize their pluralistic, inclusive, and egalitarian character" (Tal \& Geltman 2014, p. 10).

In 1991, the Ministry of Education established the Commission for Examining the State of Jewish Studies in State Education. The Commission's conclusions were that the crisis regarding Jewish studies could possibly pose a real danger and create a crisis of identity among secular Jews, to the point of "doubts regarding the legitimacy of Zionism and the legitimacy of the State of Israel" and thereby lead to "great harm to the cohesion of the collective"(Jewish Pluralism Watch, 2014). The Commission report determined that an interdisciplinary curriculum must be developed that will focus, among other things, on the acquisition of Jewish and universal values. As a result of this report, the Shenhar-Kremnitzer committee was founded, which was given responsibility, among other things, for the teaching of Jewish culture in the spirit of the Shenhar Commission.

There is a clear developmental, educational, and social process-from negating the Diaspora at the beginning of the 
period, to gradual "normalization" of the attitude towards the Diaspora to the point of changing its name (it was previously known as the Golah [exile] and now Tefutsot [the word that can literally be translated as Diaspora]) and emphasizing "Jewish peoplehood" (Dror, 2003). The thirst for Judaism is expressed in the establishment of dozens of organizations and batei midrash [learning centers] for the secular (and religious) population, including Beit Avi Chai, the Mashiv Haruach poetry journal, the Nigun Halev community, BINA-The Jewish Movement for Social Change, Beit Midrash Elul, the Shalom Hartman Institute, and the TALI Education Fund.

Detel (2015) claims that State Religious education is currently prioritized over the State system, the main stream of Israeli education that educates primarily secular, traditional, and Arab students. According to Ministry of Education official figures, students in the State Religious education stream receive larger budgets than Jewish students in the State stream, and far more than those in the Arab stream who receive the lowest allocation. This bias exists in both the elementary and high schools.

\subsubsection{Teaching Jewish Studies within the State Education System}

The severe drop in the status of Jewish studies in the State education system contributed to students' increasing feelings of alienation toward their heritage and was the basis for the establishment of the Shenhar Commission. Its recommendations, published in 1994, include the call "to strive for the teaching of Judaic subjects in a way that emphasizes their character as humanities, imparting culture and values that provide tools for building a worldview" (Shenhar Report, 1994). This aspiration has accompanied the Zionist movement since the Second Zionist Congress in 1898 which decided that "Zionism will not act in any way to infringe upon the Jewish religion" (Shafir \& Peled, 2002, p. 149). Tsabar Ben Yehoshua and Stein (2007) note in their study that in a study following-up the implementation of the report's recommendations, they found a rise during 1996-97 in both the number of schools teaching Judaism and the teaching hours allocated (Ben-Avot \& Rash, 2002, p. 157). Tsabar Ben Yehoshua and Stein also argue that we are witness to an era in which secular Torah study is on the increase. The vision of Bialik and Ahad Ha'am for deep and comprehensive study has thus been reawakened.

Zionist ideology, at its baseline level, saw "the creation of a new Jewish society" as involving the "negation of the Diaspora" as well as the generation of the educators (Hartaf, 2007). Hartaf notes in her study that the different streams that characterized the school system during the Yishuv period and the early years of the State of Israel reflected various values to shape the character of the New Jew, the "Israeli sabra". The general Hebrew education stream, opened in 1913 following the Languages War, made it its goal to strengthen the existing national unity while developing a new Jewish culture, a goal that stemmed from a trend reflecting the stream's secular tendencies (Carmon, 1985, p. 126; Lamm, 1973, pp. 72-73).

Don-Yihye and Liebman (1984) describe three periods in the attitude to religion in Eretz-Israel. The first, prior to the establishment of the State of Israel, in which there were attempts to create the New Jew and negate the Diaspora; the second, around the time of the State's establishment, which included painstaking selection during which various kinds of historic myths and symbols were adopted or rejected-for example, the Bible became a central symbol to which new symbols connected to Independence Day were added. The third period was following the Six Day War and during the 1970s, and included a "new interpretation" during which the attitude to religion was more positive and the events of the Holocaust occupied a prominent position that emphasized the correspondence between the Jewish nation, Jewish tradition, and the State of Israel (p. 476).

\subsubsection{The Education System's Division into Streams}

Inbari (2016) notes in his study that according to Ravitzky (2005), secular, national religious, and ultra-Orthodox Israelis never studied in the same education system. In many ways, they never lived on the same planet. They are strange and strangers to each other, hate each other, arrogant towards the others "based on the erroneous common premise-accepted on both sides of the barricade-that the opposing side is fated to reduce in number, fade away, and perhaps even disappear altogether" (Ravitzky, 2005, p. 258).

The existing education system perpetuates the division into sectors that divides Israeli society from within. The structure of the formal education system in Israel is extremely complex and based on various forms of classification and categorization (Weisblai \& Winninger, 2015): classification according to legal status (official education, recognized but unofficial, unrecognized private), classification according to sector (Jewish, Arab, Bedouin, Druze, Circassian), and classification according to type of inspectorate (State, State Religious, or other). Moreover, its sector-based division is not functional but rather political, and is not only because of the difference in ideological content but also the party and ethnic origin: the Chinuch Atzmai network belongs to Agudat Yisrael and serves only the Ashkenazi ultra-Orthodox population, Maayan Hachinuch Hatorani's educational institutions belong to the Shas party, and the State Religious system was created by the National Religious party and intended for the national religious population. Instead of integrating everyone 
into a united national framework, nurturing a collective sense of partnership and responsibility, the existing education system exacerbates the social division and encourages different "nations" within the same state.

In their book, Kirvah Umerivah, Yochanan Peres and Eliezer Ben-Rafael (2007) determined that "the conflict between the religious and secular is the deepest, broadest, and most central of the conflicts dividing the Jewish nation in Israel". Yonatan Cohen (1997) wrote that "one of the components that creates, maintains, and increases social schisms is the feeling of alienation between the sides and from the institutions of the opposing side. In his article, Ma'arekhet Hahinukh Keplatformah [The education system as a platform], (that was also quoted on the Hofesh website, targeting a secular audience) Yaron Yadan (n.d.) emphasizes that the structural platform of the education system described above is a complicated, wasteful, ineffective, and patchwork bureaucratic system.

\section{Methodology}

The study included a random sample of 16 State preschools from the following areas: Jerusalem, Even Sapir, Modiin, Karmiel, Ramat Gan, Moshav Ram-On, Hadera, Kiryat Motzkin, Karmeliya, Yokneam, Afula, French Carmel, and Ramat Hatishbi. The questionnaires were distributed and collected by students from the preschool track at Shaanan College, who work in these communities. The data were collected from the questionnaires (see example in the appendix) and it was researched how much, or if at all, preschool teachers in kindergartens in State and State Religious education note, teach, and emphasize the following topics: Welcoming the Sabbath ceremony, Jewish festivals, and Torah stories.

\subsection{Study Population}

Out of the 16 participating preschool teachers, only one wrote that most of the children in her preschool are from religious families. One wrote that there are always a few religious families attending her State preschool, two wrote that only one girl was from a religious home, one wrote that there were two mixed families. The other 11 preschool teachers all wrote that they had no children from religious homes in their preschool. This is illustrated in Figure 1.

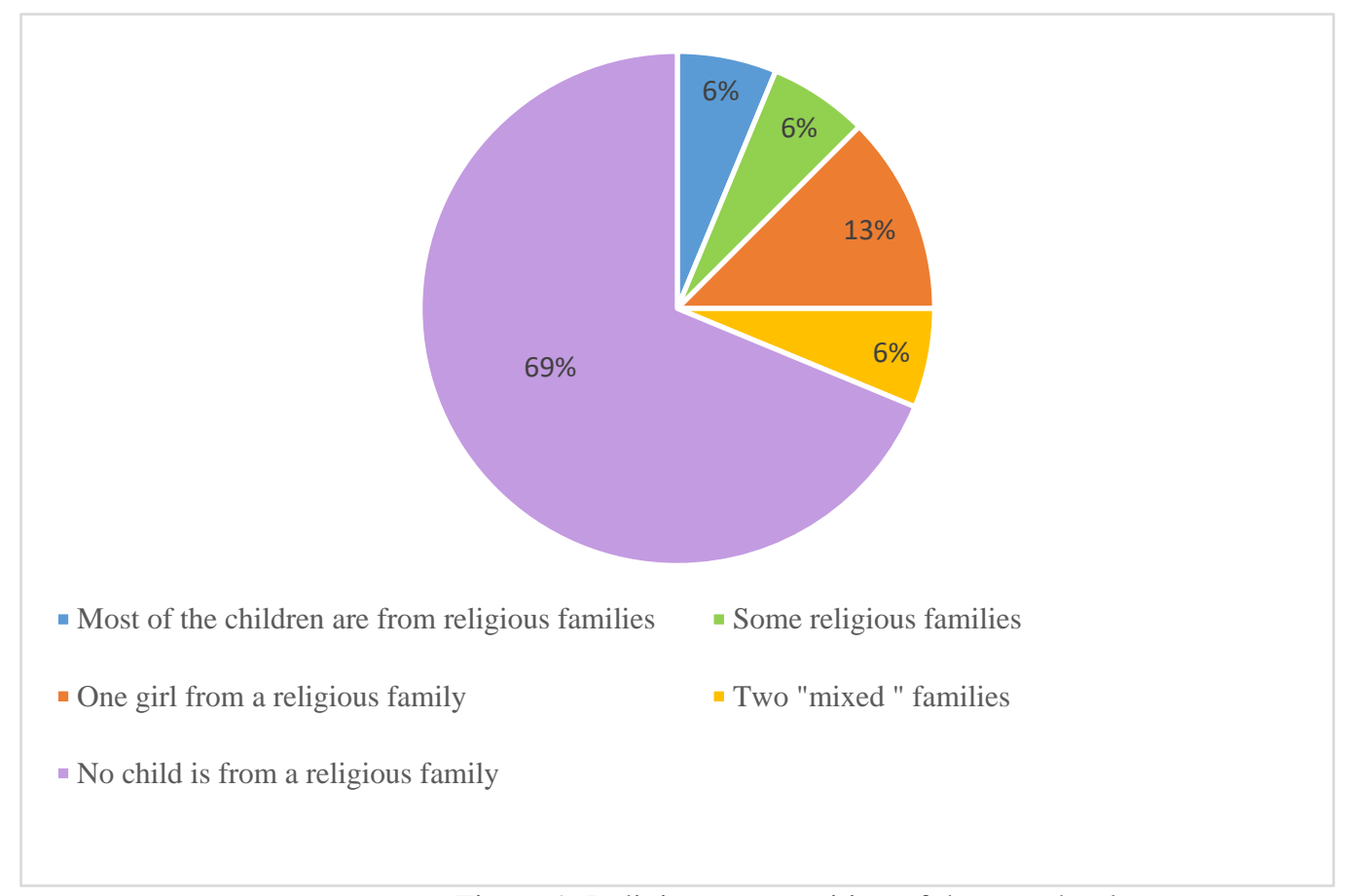

Figure 1. Religious composition of the preschools

\section{Findings and Discussion}

\subsection{Welcoming the Sabbath Ceremony in the Preschool}

In their study Tamar Rappaport and Orit Yaffa (2007) watched the Welcoming the Sabbath ceremony in several secular preschools in Israel and compared it to the Welcoming the Sabbath ceremony in preschools for ultra-Orthodox girls. They reveal that the preschool teachers in the State stream were given relatively broad autonomy to introduce new content into the ceremony. Some of them imbue it with a child-centric approach and enable the child welcoming the Sabbath to talk about himself and his family. In our sample, all 16 participating preschool teachers from the State system conduct a Welcoming the Sabbath ceremony with a set table, white tablecloth, candles, challah bread, and a wine goblet with grape juice. Two children-a boy and girl-are chosen to be the Sabbath Daddy and Sabbath Mommy. They make the blessings, 
light candles, and say the kiddush prayer over the wine and challah bread (most of the preschool teachers noted that all the children are given wine and challah, with only one teacher saying that only the "Daddy" and "Mommy" taste them), sing Sabbath songs, and dance a dance connected to the Sabbath or the days of the week.

There were some preschool teachers who added additional things. Figure 2 shows that most of the State preschool teachers have a Welcoming the Sabbath ceremony that is similar or identical to that held in the State Religious preschool. A large number (one third) of participating preschool teachers said that Friday is devoted to baking challah in the preschool.

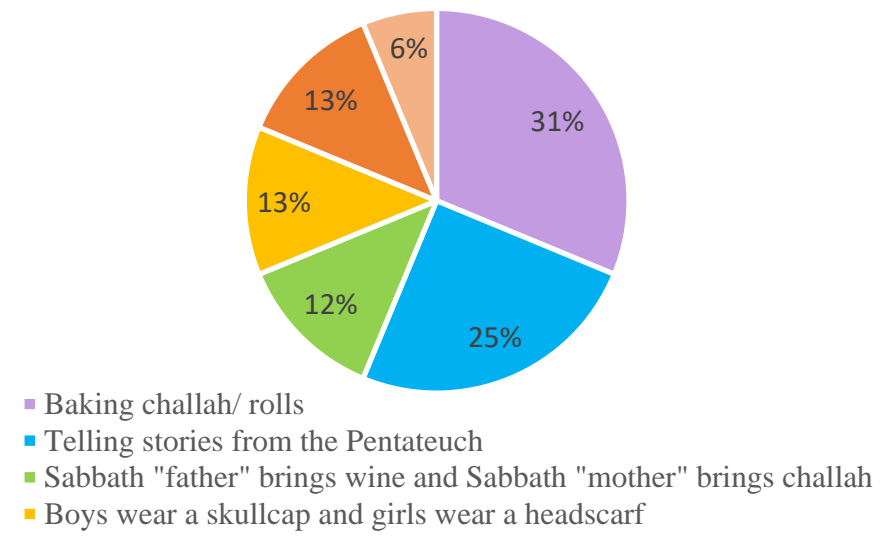

Figure 2. Form of Welcoming the Sabbath ceremony in the preschool

\subsection{Jewish Festivals}

\subsubsection{Teaching about Jewish Festivals by in State Preschools}

The preschool teachers who participated in the sample were asked what they emphasized regarding the festivals of Rosh Hashanna [New Year], Yom Kippur [Day of Atonement], Passover, and Shavuot [Pentecost]. These festivals were deliberately chosen since they contain more religious symbols than other festivals and special days and someone cannot "escape" from them to customs that can be considered less religious-festivals such as Purim (masks and costumes), the New Year for Trees (tree planting) or Lag B'Omer (when even non-religious people light bonfires). Even Sukkot [Tabernacles], considered a religious festival, is not included in the questionnaire, since many secular Jews erect a sukkah [temporary hut] for their children, to let them experience construction and creativity. The data emerging from the questionnaires to the preschool teachers shows that most preschool teachers teach about the important festival symbols for Rosh Hashanna-apple and honey, New Year's greeting cards, a pomegranate, and a shofar [ram's horn]. For Yom Kippur they teach about the meaning of asking for forgiveness and friendship, for Passover the story of the Exodus from Egypt and slavery as against freedom, and for Shavuot they emphasize bringing the first fruits to the Temple, the Seven Species with which the Land of Israel is blessed, wheat and bread, and eating dairy foods. There were, however, some preschool teachers who taught other things or in addition to the accepted standard as shown in Figure 3. 


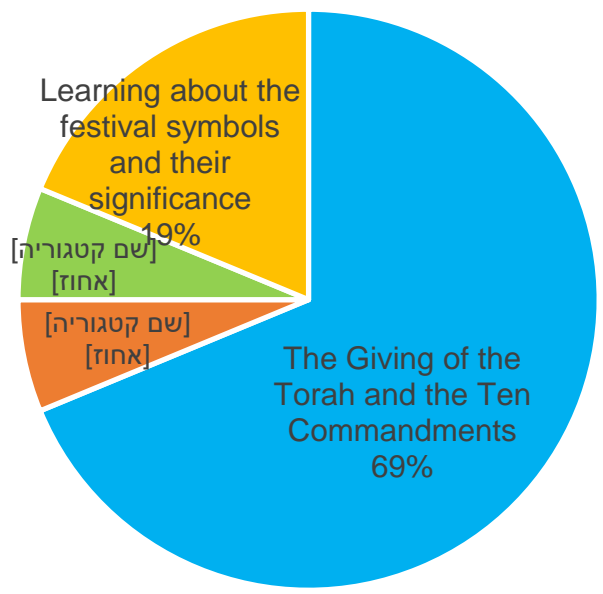

- The Giving of the Torah and the Ten Commandments

- The Book of Ruth

- The pilgrimage to Jerusalem

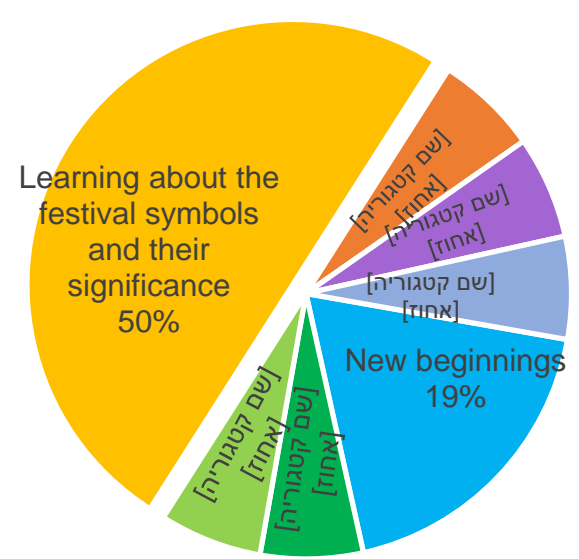

- New beginnings

- Good deeds

- Repentance

- Learning about the festival symbols and their significance

- Road safety

- Prohibitions on Yom Kippur

- Doesn't teach about Yom Kippur

Figure 4. How the topic of Rosh Hashanna and Yom Kippur is addressed in the State preschool 


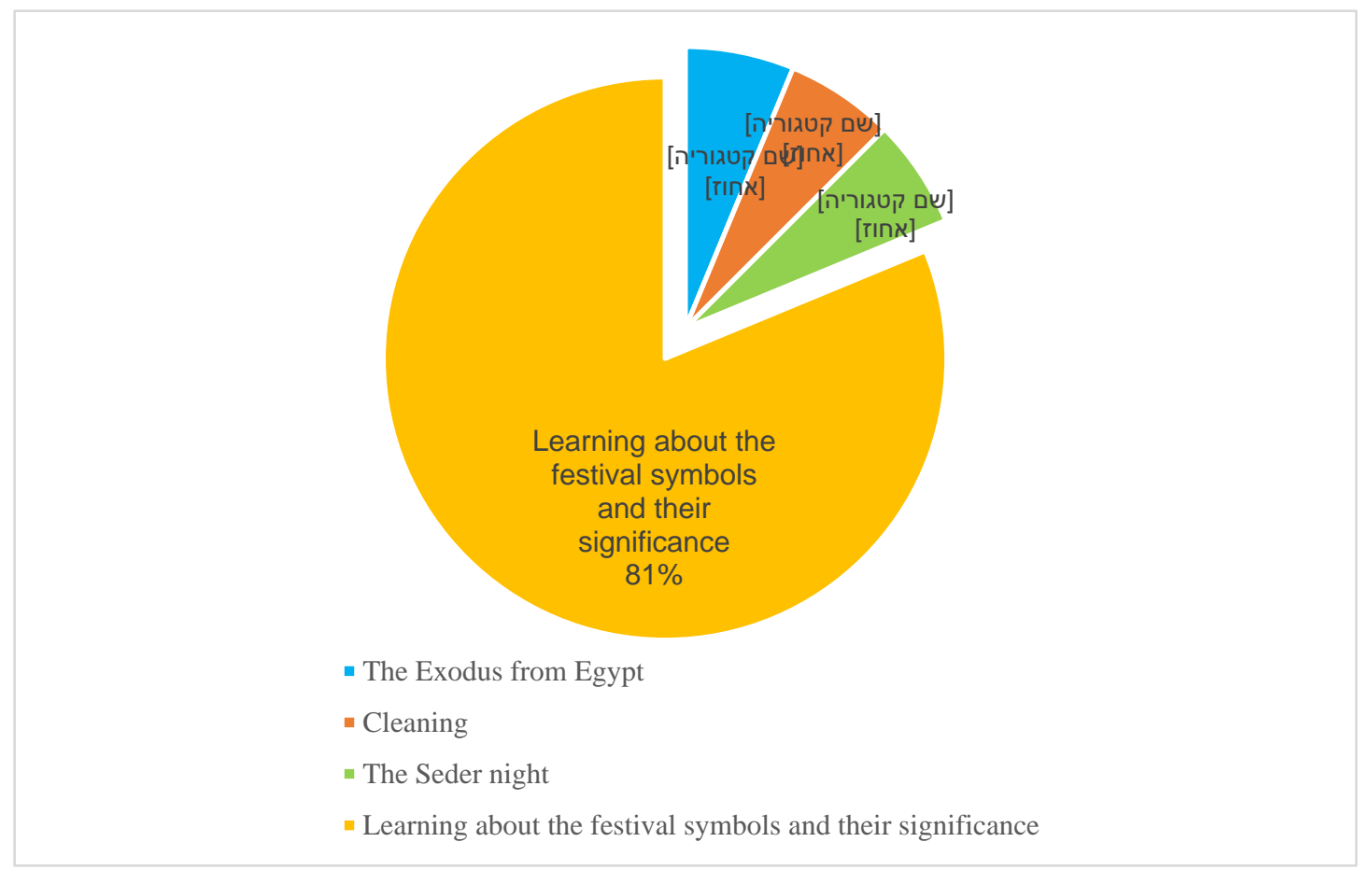

Figure 3. How the topic of Passover is addressed in the State preschool

The figures show that most preschool teachers teach religious values for the festivals of Rosh Hashanna, Yom Kippur, Passover, and Shavuot. Of the 16 preschool teachers who participated in the sample, 11 teach about Shavuot as the festival of giving of the Torah and the Ten Commandments, emphasizing the commandment to honor parents. Only 3 of the 16 focus on "new beginnings" for Rosh Hashanna instead of religious values.

Regarding religious festivals and special days, compared to studies carried out in schools, Posner $(2005,37)$ notes that "activity regarding Jewish festivals and special days comprises the 'default' for Jewish education in State schools... and not only elementary schools in Tel Aviv, but also high schools". Sever and Dushnik (2006, p. 57) also note that in post-elementary schools "have similar content to that mentioned in elementary schools... Judaism was discussed mainly in regard to the calendar, and particularly the festivals." However they add that there is a difference in the scope and content of the activities. While the elementary schools that were surveyed carried out ceremonies linked to religious occasions (Jewish festivals), the post-elementary schools mostly marked the occasions with more of a national, rather than religious, character, particularly memorial day ceremonies (p. 60).

One of the topics with the largest number of texts in the elementary school readers was "festivals and memorial days". The creators of the education system saw Jewish festivals and special days as having made the greatest contribution to the existence of the Jewish nation in the Diaspora, and therefore wished to shape Israeli identity using the patterns and content of a "national calendar" that would include the traditional festivals alongside new ones which had become a tradition within the Yishuv (p. 34). Most of the texts on this topic emphasize the nationalist-Israeli connection, while "the God of Israel, and the religious commandments, stories, prayers, and rituals, occupy only a marginal position in the readers". This trend brought about the creation of an "Israeli-centric without religious values" approach (p. 37) that was sharply criticized, since it led to a generation growing up in the Land alienated to Judaism due to its unfamiliarity with it (p. 38).

One of the most prominent examples of integrating Jewish and Israeli content is the Jewish calendar with its Sabbaths, festivals, and special days. Analysis of how ceremonies and festivals were celebrated before and after the State's establishment shows that one of their main purposes was to strengthen the connection and identification with the nation and the motherland, with them reflecting "two sides of the same coin" (Ben-Amos, 2004, p. 288).

Schweid (1996) lists three factors on which the opposition to the religious establishment was based, which he believes influenced the attitude of non-religious Jews to festivals and special days. Firstly, secular philosophy emphasizes opposition to the religious establishment and the faith content that secular people deny. Secular people prefer subjective, spontaneous, and non-committal means of expression, as opposed to commitment to ceremonies and religious laws. Secondly, the opposition also emanates from the dynamic and innovative pace of modern lifestyles. Secular people view repetitive patterns of expression, such as festivals, as monotonous and boring frameworks. Thirdly, for a festival to be an innovative experience rather than a fixed, routine pattern, it demands that everyone participates creatively in the 
celebration-and this contradicts the modern pattern of pleasure in which a performer entertains the audience. Festivals are celebrated with independent activity, together with other people, not through them. Schweid writes that educators are responsible for the initial task, to teach the students that the cultural-spiritual view of the festival contains a topical element, which secular culture cannot provide, and which is the root of every person's development and expression. Secondly, the educator must show the students the creative, novel, and one-time dimension in repeating a fixed event. Thirdly, she must persuade the students of the importance of personal expression during the celebration even though she is opposed to the type of pleasure that they are used to (pp. 241-244). According to this approach, a festival is a one-time opportunity for new expression and creativity.

\subsection{Studying Torah in the Preschool}

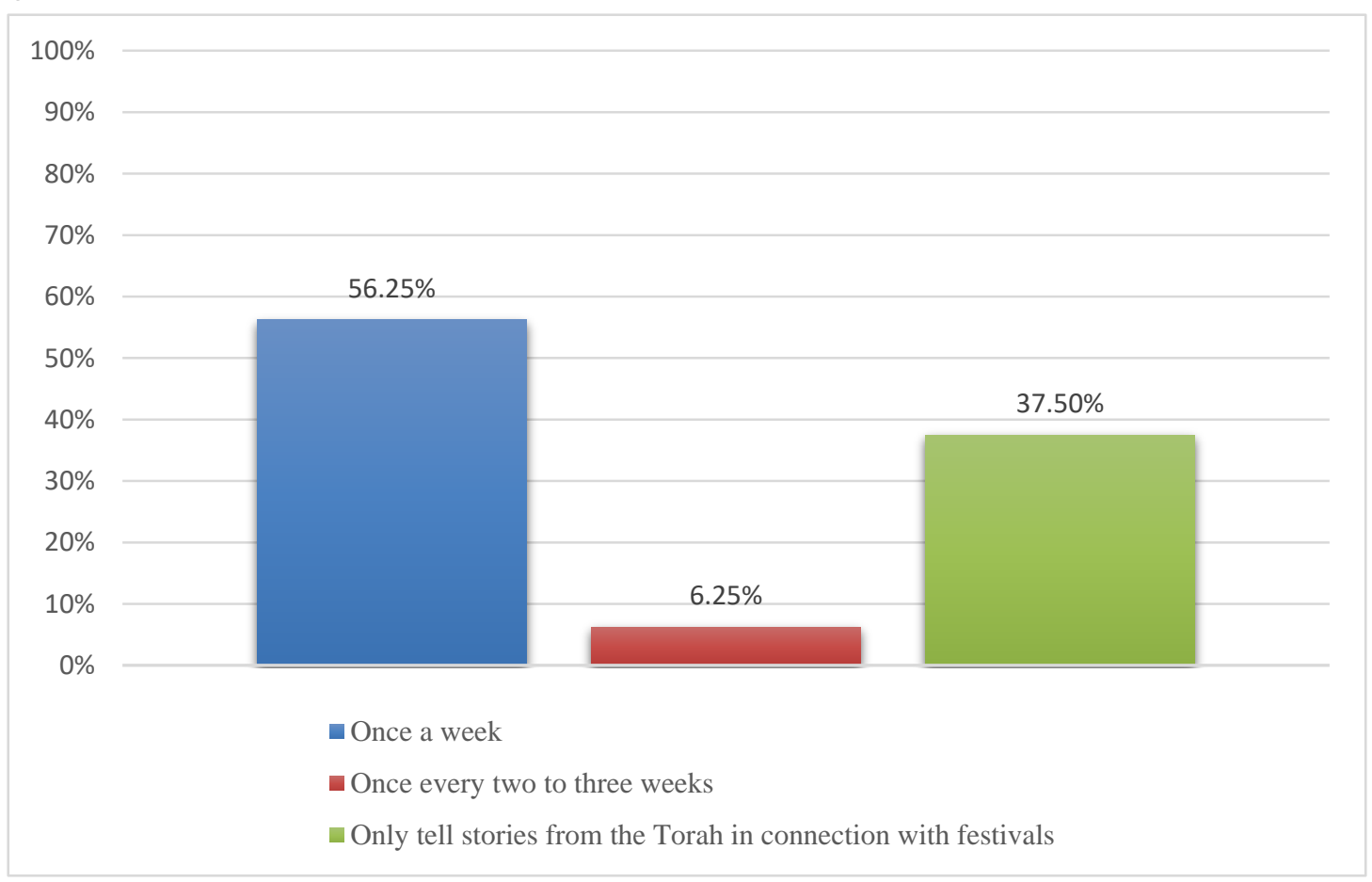

Figure 4. Frequency of telling stories from the Torah

\subsection{Other Religious Content in State Preschools}

The statistics show that most of the preschool teachers primarily tell the stories from Genesis, which are the most concrete and descriptive of all the Pentateuch stories. At the same time, a not insignificant number of preschool teachers do not tell Torah stories at all. The findings indicate so far that each State preschool teaches Judaism differently. The variations emanate from two main factors: parental expectations, or the preschool teacher's personality and her willingness to teach this content, or sometimes both factors are combined. In some preschools, the preschool teacher's personal beliefs were incongruent with her professional ones. This may be the result of life experience, the teacher's childhood experiences, or her professional attitude.

Most of the State preschool teachers who participated in the study make sure to hold a Welcoming the Sabbath ceremony in the preschool, with the same format as in the State Religious preschools. Most of the State preschool teachers teach about the giving of the Torah and the Ten Commandments on the Shavuot festival, and most tell stories from the Torah weekly-adapted for children-from the book of Genesis. Most preschool teachers reported that they had no religious-based conflicts with the parents (one even said that the parents approached her and told her about a positive experience that was the result of learning Torah stories in the preschool), but five (nearly one third of the preschool teachers) reported a conflict: one wrote that every year there are always one or two parents who complain about the Welcoming the Sabbath ceremony or values taught in the preschool. The second wrote about the conflict with the parents of a non-Jewish girl who attended the preschool and brought non-kosher sausage to eat. The third wrote about a mother from a religious family who wanted to transfer her son to a religious preschool. The preschool teacher told the mother that the child had already adapted to the preschool and it was a shame to take him out at this stage, and she would do what she could to only have kosher food in the preschool. The mother brought wrapped cupcakes which the preschool teacher gives the child on birthdays. In addition, when there is a baking activity in the preschool, the teacher sifts the flour and if one of the parents brings a treat with particular kosher certification or that is dairy she tells the mother and asks if she can give it 
to her son. The fourth played the song "Whoever believes is not afraid" and one of the parents complained that she wanted to make the children religious. Likewise, she uses the phrase, "the Holy One, blessed be He" and received a complaint from the inspector that she must say God's explicit name. The preschool teacher writes that she felt this was religious coercion by the inspector. The fifth brought a rabbi to the preschool to blow the shofar and the parents preferred that he would not come. After she explained things to them, she says the action was accepted.

Most teach religious values, not because they are obligated to by the education system, but because that is what they want to do. They have a connection with Jewish values and view it as important to teach them in the preschool. Some think religious coercion exists in Israel (most noted the issues of Sabbath observance, kosher food, separation of religion from the State and army), but they do not believe this coercion has anything to do with preschool education. In addition, with the exception of two teachers, they do not cooperate with, or have contact, with preschool teachers from the religious sector.

Two preschool teachers added several personal thoughts unconnected with the questionnaire. One said that when she had attended preschool, the teacher had told them Jews must fast on Yom Kippur and since her parents did not, she was afraid they would die. The second preschool teacher related that she feels she lacks knowledge of Jewish sources because she emigrated from Russia and she wants to learn more. She also does not teach the children what she doesn't know, so as not to confuse them or tell them something wrong.

\section{Conclusions}

The definition of Jewish identity is subject to debate, and there is no one firm definition accepted by everyone. Different movements and sectors imbue the concept with interpretation that matches their views and lifestyles. Even secular Judaism has several interpretations of Jewish identity-defining it as identity based on culture, nationalism, and Zionism. The study reveals that State preschools provide education regarding Jewish values. Just like there are many different opinions regarding the definition of "Jewish identity", so the different approaches are expressed in the State education system. Each approach defines desirable Jewish identity, and the student absorbs Jewish education according to how it is understood by each specific approach. In the State preschools examined in this article, the emphasis is on culture and nationalism, as connected to values of good behavior towards others. Likewise, the findings show that Jewish education at an early age is influenced by the personality and inner world of the preschool teacher and her own connection to Jewish content.

\section{Notes}

Note 1. Throughout this article, "State (pre)schools" [mamlakhti] refer to government-funded (pre)schools which are Jewish and secular in nature. This is in contrast to the other three types of government-funded schools: State-Religious, Arab, and Chinuch Atzmai (ultra-Orthodox).

Note 2. In this article, the word Torah is used to mean the Pentateuch, the first five books of the Jewish Bible, which is read in the synagogue over the course of a year, one portion weekly.

Note 3. The State of Israel as a democratic Jewish state, a discussion held during the World Congress of the The World Union of Jewish Studies together with AVI CHAI, Jerusalem: The Hebrew University of Jerusalem, 1989.

\section{References}

Agasi, Y. (1993). Ben dat u'le'um: Likrat zehut le'umit Yisra'elit [Between faith and nationality: Towards an Israeli national identity] (2nd ed.). Tel Aviv: Papyrus.

Ahad, Ha'am. (1954). Kol kitvey Ahad Ha-Am [The complete writings of Ahad Ha'am]. Tel Aviv: Dvir.

Almog, O. (1997). Hatsabar - Diyukan [The Sabra - A portrait]. Tel Aviv: Am Oved.

Ben-Amos, A. (2004). Bema'agal haroked vehamezamer: Teksim vehagigot patri'otitiyim bahevrah hayisra'elit [In the dancing and singing circle: Patriotic rituals and celebrations in Israeli society]. In D. Bar-Tal and A. Amos (Eds.), Patri'otizem: Ohavim otkha moledet [Patriotism: Homeland love] (pp. 275 -315). Tel Aviv: Hakibbutz Hameuchad,

Ben-Avot, A., \& Rash, N. (2002). Hinukh Yehudi behativot benyaim mamlakhti'ot beyisra'el [Jewish education in junior high schools in Israel]. Jerusalem: The NCJW Research Institute for Innovation in Education, The Hebrew University of Jerusalem.

Ben-Rafael, E. (2001). Zehuyot Yehudi'ot: Teshuvot hakhmey Yisra'el l'ben Guriyon [Jewish identities: The answers of the Sages of Israel to Ben-Gurion]. Beersheva: Ben-Gurion University of the Negev Publishing, Ben-Gurion Heritage Institute.

Bystrov, E., \& Soffer, A. (2010). Yisra'el demografia 2010 - 2030: Baderekh limdinah datit [Israel, demography 2012-2030: On the way to a religious state]. Haifa: Chaikin Chair in Geostrategy, University of Haifa. 
Carmon, A. (1985). Hahinukh beyisra'el: Sugi'ot uba'ayot [Education in Israel: Issues and problems]. In Hinukh Bahevrah Mithaveh [Education in an existential society], 2 vols (pp. 117-186). Tel Aviv: Hakibbutz Hameuchad \& The Van Leer Institute.

Cohen, Y. (1997). Itonut lehatsi ha'am [Journalism for half the nation]. Retrieved May 6, 2019, from https://www.itu.org.il/?CategoryID=494\&ArticleID=1102

Davidson, M. (2000). Hishtakfut shel rekivey hazehut hayisra'elit bemikra'ot lesifrut bishnot hahamishim vehashishim [The reflection of particles of the Israeli identity in literature textbooks during the Fifties and Sixties]. Zmanim: A Historical Quarterly 72: 32-43. http://www.jstor.org/stable/23437122

Detel, L. (2015). Seder ha'adifuyot shel naftali benet: Hinukh mamlakhti-dati, limudey dat u'midrashot l'nashim [Naftali Bennett's order of priorities: State Religious education, religious studies, and institutes of Jewish studies for women]. The Marker. Retrieved from https://www.themarker.com/news/education/1.2632729

Don-Yihye, E. (1989). Mamlakhti'ut veyahadut behaguto u'vemedinitiyuto shel Ben Gurion [Statism and Judaism in Ben-Gurion's philosophy and politics]. Hatziyonut 14 : https://humanities.tau.ac.il/sites/humanities.tau.ac.il/files/media_server/humanities/zionism/\%D7\%A6\%D7\%99\% D7\%95\%D7\%A0\%D7\%95\%D7\%AA/\%D7\%99\%D7\%93/4.pdf

Don-Yihye, E., \& Liebman, C. S. (1984). Hadilema shel tarbut masortit bimdinah democratit: Temurot vehitpathuyot b'dat ha'ezrahit shel Yisrael [The dilemma of reconciling traditional culture and political needs: Civil religion in Israel]. Megamot 28(4): 461-485.

Dror, Y. (2003). Mishlilat hagalut l'tipuah hatoda'ah hayehudit' b'ma'arekhet hahinukh hayisra'elit, 1920-2000 [From negation of the Diaspora to nurturing Jewish awareness in the Israeli educational system]. Panim 24: 59-69. https://www.itu.org.il/?CategoryID=536\&ArticleID=1577

Fischer, S. (2003). He'arot al dat u'le'umiut bezehut hakolektivit hayisra'elit [Notes on religion and nationalism in Israeli collective identity]. In S. N. Eisenstadt, R. Brayer-Garb, \& T. Kochavi (Eds.), Zehuyot, Kolektiviyut, Ezrahut Vezirah Tsiburit [Identities, collectivism, citizenship and the public arena] (pp. 53-68). Jerusalem: The Van Leer Forum for Public Discourse.

Hartaf, H. (2007). Lihiyot Yisra'eli vegam Yehudi: Hinukh hevrati vehavnayat hazehut [To be both Israeli and Jewish: Informal education and building an identity. (Unpublished doctoral dissertation). University of Haifa, Haifa, Israel.

Inbari, A. (2016). Nahuts kor hitukh, aval hapa'am Yehudi [We need a melting pot, but this time a Jewish one]. Retrieved from http://shalem.ac.il/content-channel/we-need-a-jewish-melting-pot/

Israel Ministry of Education. (2017). Jewish-Israeli education, the curriculum for State education, grades 1-9. Jerusalem: Ministry of Education.

Jewish Pluralism Watch. (2014). Hamashber belimudey hayahadut alul lihyot sakanah shel mamash u'litsor mashber zehut bamerhave hayehudi hahiloni [The crisis in Jewish education cause a real crisis in identity in the secular Jewish arena]. Retrieved from http://www.mishmar.org.il/page.php?p=11001

Kaplan, M. (2004). Lehidush penay hatsionut [Renewal of Zionism]. Jerusalem: World Zionist Organization and Mordecai M. Kaplan Center for Jewish Peoplehood.

Kimmerling, B. (1998). Hayisra'elim hahadashim: Ribuy tarbuyot lelo rav-tarbutiyut [The new Israelis: Multiple identities without multiculturalism]. Alpayim 16: 264-308.

Lamm, Z. (1973). Metahim ide'ologiyim: Ma'avakim al matarot hahinukh [Ideological tensions: Struggles over educational goals]. In C. Ormian (Ed.), Hahinukh Beyisra'el [Education in Israel]. Jerusalem: Ministry of Education and Culture.

Lax, O. (2017). Migzar holekh l'ibud [A sector is disappearing]. Basheva. Retrieved from https://www.inn.co.il/News/News.aspx/346184

Levi, S., Levinhson, H., \& Katz, E. (2002). A portrait of Israeli Jewry: Beliefs, observances, and values among Israeli Jews 2000. Jerusalem: The Guttman Center of the Israel Democracy Institute for the AVI CHAI Foundation.

Mimron, Y. (2009). Darush shinuy: Al hatsorekh behinukh Yehudi-Masorti ra'uy [A change is needed: Regarding the need for proper Jewish-traditional education]. Deot 85. Retrieved from https://toravoda.org.il/\%D7\%9B\%D7\%AA\%D7\%91\%D7\%94/\%D7\%93\%D7\%A8\%D7\%95\%D7\%A9-\%D7\%A9 \%D7\%99\%D7\%A0\%D7\%95\%D7\%99-\%D7\%A2\%D7\%9C-\%D7\%94\%D7\%A6\%D7\%95\%D7\%A8\%D7\%9A-\% D7\%91\%D7\%97\%D7\%99\%D7\%A0\%D7\%95\%D7\%9A-\%D7\%99\%D7\%94\%D7\%95\%D7\%93\%D7\%99-\%D7\% 9E\%D7\%A1\%D7\%95\%D7\%A8\%D7\%AA/ 
Oron, Y. (1993). Zehut Yehudit-Yisra'elit [Jewish-Israeli identity]. Tel Aviv: Poalim and Kibbutz College of Education.

Peres, Y., \& Ben-Rafael, E. (2007). Kirvah umerivah: Shesa'im bahevrah hayisra'elit [Closeness and fighting: Rifts in Israeli society]. Tel Aviv: Am Oved, pp. 15, 95.

Posner, M. (2005). Ma yehe al hamoreshet v'al hatushba? Al ma'amadam hamithazek akh adayin bilti yatsiv shel limuday hayahadut bevatey sefer mamlkhtiyim b'tel aviv [What will happen to the heritage and the Oral Law? Regarding the increasingly strong, but still unstable status of Jewish studies in State schools in Tel Aviv]. (Unpublished master's thesis). Tel-Aviv University, Tel Aviv, Israel.

Prego, U. (1989). Hazehut hayehudit shel no'ar Yisra'eli, 1965-1985 [The Jewish identity of Israeli youth, 1965-1985]. Yahadut Zemanenu 5: 259-285.

Rappaport, T., \& Yaffa, O. (2007). Al hinukh vehiloni'ut: Kabalat Shabbat began hayeladim halo dati beyisra'el [About education and secularism: Welcoming the Sabbath in the Israeli non-religious preschool]. In S. Shlasky, \& Alpert, B. (Eds.), Derakhim biktivat mehkar eikhatuni, mipiruk hametsi'ut lehavnayatah k'text [Methods of writing a qualitative study, from dismantling the reality to structuring it as a text] (pp. 231-271). Tel Aviv: Mofet Institute,

Ravitzky, A. (2005). Herut al haluhot: Kolot aherim shel hamahshavah hadatit [Freedom on the tablets: Alternative voices of religious thought]. Tel Aviv: Am Oved.

Samucha, S. (2000). Hamishtar shel Medinat Yisra'el: Demokratiya ezrahit, e-demokratiya o democratiya etnit? [The State of Israel's regime: A civil democracy, a non-democracy, or an ethnic democracy?] Israeli Sociology 2(2): 565-630.

Sarid, A. (2012). Hinukh l'etikah u'musar al pi tokhni'ot halimudim beyisra'el [Education for ethics and good behavior according to the Israeli curriculum]. Tel Aviv: Mofet Institute. Retrieved from http://yozma.mpage.co.il/SystemFiles/23061.pdf

Schweid, E. (1996). Hatsiyonut sheaharey hatsiyonut [The Zionism after Zionism]. Jerusalem: World Zionist Organization.

Schweid, E. (2000). Hinukh humanisti-Yehudi beyisra'el [Humanist-Jewish education in Israel]. Tel Aviv: Hakibbutz Hameuchad, pp. 45-77.

Schweid, E., \& Porat, Y. (1991). Du-siakh al hazehut hayehudit hayisra'elit [Jewish Israeli identity]. Iyunim: Multidisciplinary Studies in Israeli and Modern Jewish Society, 1, 3-11. https://in.bgu.ac.il/bgi/iyunim/1/eliezer.pdf

Sever, R., \& Dushnik, L. (2005). Tarbut Ivrit bema'arakhet hahinukh shel ha'ir Tel Aviv Yafo [Hebrew culture in the education system of the city of Tel Aviv-Jaffa]. Research report submitted to the Municipality of Tel-Aviv.

Shachar, I. (2017). Hatenakh kebasis lazehut uletarbut hayisra'elit [The Bible as the basis of Israeli identity and culture]. Retrieved from http://mikrarevivim.blogspot.com/2013/09/2013.html

Shafir, G., \& Peled, Y. (2002). Being Israeli: The dynamics of multiple citizenship. Cambridge: Cambridge University Press. https://doi.org/10.1017/CBO9781139164641

Shapira, A. (1997). Yehudim hadashim Yehudim yeshanim [New Jews, old Jews]. Tel Aviv: Am Oved.

Shapira, A. (2007). Yehudim, Tsionim u'mah shebenehem [Jews, Zionists, and what is between them]. Tel Aviv: Am Oved, pp. 247-258.

Shenhar Report. (1994). Tarbut Yehudit ba'olam mishtaneh, livdikat matsavam shel limudey hayahadut bahinukh hamamlakhti [Jewish culture in a changing world, examining the state of Jewish studies in State education]. Jerusalem: Ministry of Education.

Tal, R., \& Geltman, B. (2014). Annual assessment - The Jewish People: Situation and dynamics, 2013-2014. The Jewish People Policy Institute (Established by the Jewish Agency for Israel), pp. 5-45. Retrieved from: http://jppi.org.il/new/wp-content/uploads/2014/08/2013-2014-Annual-Assessment_WEB.pdf

Tsabar Ben Yehoshua, N., \& Stein, A. (2007). Yahadut veyisra'eliyut: Hagishah hahilonit. Panim 40. Retrieved from https://www.itu.org.il/?CategoryID=1215\&ArticleID=9649

Tzivyon, A. (1988). 'Kekhol hagoyim' v'am segulah': Zikato shel Ben-Gurion latenakh ['Like all the nations' and 'the Chosen People': Ben-Gurion's bond to the Bible]. Shadmot: Organ of the Kibbutz Movement 107: 77-88.

Weisblai, E., \& Winninger, A. (2015). Ma'arerkhet haninukh beyisra'el: Sugiot nivharot bithum isukah shel va'adat hahinukh, hatarbut, vehasport shel hakneset [The education system in Israel: Selected issues as discussed by the Knesset Education, Culture, and Sport Committee]. Knesset Research and Information Center, pp. 1-66. Retrieved from 
http://fs.knesset.gov.il/globaldocs/MMM/f7536b58-e9f7-e411-80c8-00155d010977/2_f7536b58-e9f7-e411-80c8-0 0155d010977_11_10259.pdf

Yadan, Y. (n.d.). Ma'arekhet hinukh keplatformah limdinah normalit [An education system as a platform for a normal state]. Retrieved

from http://www.orr.org.il/index.php?option=com_content\&view=article\&id=215:2012-04-04-23-26-42\&catid=20\&Ite $\operatorname{mid}=34$

Zelba, M. (2017). Demografia shel hadatiyut: Tahalikhei hilun betsibur hadati vehamasorati [The demography of religiosity: Secularization processes in the religious and traditionally observant population]. Chotam Organization. Retrieved from https://www.chotam.org.il/media/37347/demography-of-religiosity.pdf

\section{Copyrights}

Copyright for this article is retained by the author(s), with first publication rights granted to the journal.

This is an open-access article distributed under the terms and conditions of the Creative Commons Attribution license which permits unrestricted use, distribution, and reproduction in any medium, provided the original work is properly cited. 